\title{
Ultrastructural changes in the Haemonchus contortus cuticle exposed to Acacia mearnsii extract
}

\section{Alterações ultraestruturais da cutícula de Haemonchus contortus expostos ao extrato de Acacia mearnsii}

\author{
Eidi Yoshihara ${ }^{1 *}$; Alessandro Pelegrine Minho²; Victor Bittencourt Dutra Tabacow ${ }^{3}$; \\ Sérgio Tosi Cardim 3 ; Milton Hissashi Yamamura ${ }^{4}$
}

\begin{abstract}
The parasite Haemonchus contortus is one of the most pathogenic for small ruminants in tropical and subtropical regions worldwide, including Brazil. The objective of this study was to evaluate the structural changes induced in adult $H$. contortus after in vitro contact with Acacia mearnsii extract (AE), using scanning electron microscopy. Adult nematodes were collected from a naturally infected lamb. In the in vitro assay the parasites were placed in contact with $\mathrm{AE}\left(100 \mathrm{mg} \mathrm{ml}^{-1}\right)$, for two hours at $37^{\circ} \mathrm{C}$. The nematodes used in the assays (exposed to $\mathrm{AE}$ and the negative controls) were analyzed using an electron scanning microscope (quadruplicate per treatment). In all replicates, similar morphological alterations were observed on the entire extension of the cuticle of the specimens that remained in contact with the EA in vitro assays, none significant lesion was observed in the negative control (not exposed to AE). These results indicate the direct action of EA on the cuticle of $H$. contortus in in vitro trials.
\end{abstract}

Key words: Gastrointestinal nematodes, scanning electron microscopy, structural changes, tannins

\section{Resumo}

Haemonchus contortus é um dos parasitos mais patogênicos para pequenos ruminantes em regiões tropicais e subtropicais em todo o mundo, inclusive no Brasil. O objetivo do trabalho foi analisar alterações ultraestruturais na cutícula de $H$. contortus após contato com extrato de Acacia mearnsii. Os parasitos expostos ao extrato de Acacia mearnsii (EA) e os controles negativos foram analisados ao microscópio eletrônico de varredura. No teste in vitro, adultos de $H$. contortus foram coletados de um ovino naturalmente infectado, e os parasitos foram colocados em contato com o EA $\left(100 \mathrm{mg} \mathrm{mL}^{-1}\right)$, durante duas horas à $37^{\circ} \mathrm{C}$. Os nematódeos expostos ao EA apresentaram alterações morfológicas em toda a extensão da cutícula. As alterações morfológicas não foram observadas no controle negativo. Estes resultados indicam a ação direta do EA na cutícula de $H$. contortus.

Palavras-chave: Alterações ultraestruturais, microscopia eletrônica, nematódeos gastrintestinais, taninos

1 Pesquisador, Agência Paulista de Tecnologia dos Agronegócios - Polo Regional Alta Sorocabana, APTA, Presidente Prudente, SP, Brasil. E-mail: eidi@apta.sp.gov.br

2 Pesquisador, Empresa Brasileira de Pesquisa Agropecuária, Pecuária Sul, EMBRAPA, Bagé, RS, Brasil. E-mail: alessandro. minho@embrapa.br

3 Discentes do Programa de Pós-Graduação em Ciência Animal, Universidade Estadual de Londrina, UEL, Londrina, PR, Brasil. E-mail: victor.tabacow@gmail.com; stcardim@hotmail.com

4 Prof. Dr., UEL, Londrina, PR, Brasil. E-mail: yamamura@uel.br

* Author for correspondence 


\section{Introduction}

Infections by trichostrongyles are one of the main limitations for efficient sheep production in temperate and tropical areas, especially when the abomasal parasite Haemonchus contortus is involved (HOSTE et al., 2012).

However, the frequent use of these anthelmintic drugs has given rise to drug-resistant populations. Together with this, anti-parasitic drug residues in food, as well as environmental polluting, have pushed the scientific community to seek healthier and more sustainable control of parasites (WALLER, 2006).

Throughout the last ten years, several studies have been carried out with plants rich in condensed tannins (CT), their main focus being the use of such in the control of GIN in small ruminants (MARLEY et al., 2003; MINHO et al., 2008; KATIKI et al., 2013).

CT's are secondary metabolites in plants and demonstrate anthelmintic properties when used in naturally or experimentally infected sheep. The modes of action of these anthelmintic properties remain obscure (HOSTE et al., 2006). Two hypotheses have been developed to explain the anthelminthic properties of tannins. Their direct effect may be explained by the interaction of the tannin on the surface of parasites, given the affinity of the tannins with proteins. The second hypothesis supposes an indirect effect, or rather an increase in the animal's own immunological response against the helminthes as a result of the increase in the absorption of proteins and amino acids in the small intestine given the ability that tannins have in protecting proteins in the animals own diet from ruminant degradation (HOSTE et al., 2006).

Studies of the Acacia mearnsii extract (AE) as a source of CT are currently being developed in order to evaluate their usefulness in the treatment of GIN in sheep. In vitro and in vivo results have demonstrated effects against larvae and adult parasites, specifically as regards the reduction of faecal egg count (FEC), as well as keeping the firststage larvae from feeding, and overall reduction of larval population. This indicates that the acacia extract contains active substances responsible for the anti-helminthic action (CENCI et al., 2007; MINHO et al., 2008, 2010; MAX, 2010).

Ultrastructural changes induced in GIN cuticle have been described by Hoste et al. (2006), as they analyzed the direct action of CT on Trichostrongylus colubriformis. In this study, they describe the existence of transverse wrinkles on the surface of the nematodes. Also analyzing the cuticle ultrastructural changes, Martínez-Ortíz-DeMontellano et al. (2013) describes the presence of transverse and longitudinal wrinkles on the cuticle of $H$. contortus upon contact with sources of CT.

The purpose of this paper was therefore to evaluate morphological ultrastructural changes induced in the adults $H$. contortus after in vitro contact with AE.

\section{Material and Methods}

\section{Source of condensed tannins}

The source of CT utilized in these experiments was the commercial extract from the bark of Acacia mearnsii (general purpose acacia extract, Seta $\operatorname{Sun}^{\circledR}$. Seta S.A.). This extract contains $15 \%$ of CT determined by the HCI-Butanol method, according to the methodology described by Porter et al. (1986). The tested concentration of aqueous AE $(100 \mathrm{mg}$ $\mathrm{mL}^{-1}$ ) was the highest dilution that could be made in the laboratory without the use of other solvents that could interfere on the results.

\section{In vitro assay}

\section{Adult Haemonchus contortus}

The adult parasites utilized in the in vitro test were collected from a naturally infected sheep 
from the region of Londrina, which was kept in the isolation ward of the Londrina State University Veterinarian Hospital receiving tannin-free diet. The sheep was euthanized and the abomasum collected, transferred to a lab and opened in order to collect the adult parasites.

\section{Exposure of the parasites to the extract}

The parasites were placed in petri dishes containing $5 \mathrm{~mL}$ of saline solution ( $\mathrm{NaCl} 0.9 \%$ at 37 ${ }^{\circ} \mathrm{C}$ ) to eliminate possible contamination from the other contents of the sheep's stomach. From this moment on, all the tests with the parasites were conducted at $37^{\circ} \mathrm{C}$. The parasites from the negative control group were submerged only in saline solution; nematodes from treated group were exposed to the AE diluted in distilled water at a concentration of $100 \mathrm{mg} \mathrm{mL}$ ${ }^{1}$. In this experiment, four parasites were subjected to treatment (AE exposed for two hours) and four were used as negative control (incubated in saline solution for four hours). After the incubation period, the parasites from AE-treated group were kept in the saline solution for more two hours, and the solution was changed every thirty minutes to remove any excess of the solution containing the extract (total period of incubation was four hours).

Specimen processing for electron-scanning microscope (ESM) analysis

For the preserving of the specimens obtained in test, a modified Karnovsky process was used, composed of $5 \%$ glutaraldehyde in a phosphate emulsifier at 0.1M pH 7.4 (KARNOVSKY, 1965). After 24 hours of stabilization at $4{ }^{\circ} \mathrm{C}$, they were washed three times in the phosphate emulsifier. Next, they were post-preserved in $1 \%$ osmium tetroxide in a phosphate emulsifier ( $\mathrm{pH} 7.4$ for 1 hour). Then the specimens were washed and dehydrated in a series of increasing ethanol solutions (70 to $100{ }^{\circ} \mathrm{GL}$ ).

The specimens were then dried to their critical point using a Critical Point Dryer CPD 030 (Baltec), mounted on slides and covered in gold using a Sputter Coater SCD 050 and analyzed using an electron-scanning microscope FEI Quanta 200 in the Electron-scanning and Micro-analyses laboratory at Londrina State University.

\section{Results}

Figure 1 shows the ultrastructural changes found in all of the $H$. contortus adult nematodes after two hours of in vitro exposure to the $\mathrm{AE}$ at a concentration of $100 \mathrm{mg} \mathrm{mL}^{-1}$. The modifications found in the treated group were present in all the analyzed adult parasites (quadruplicate), though the analyses were limited to the superficial integument, ruptures evident can be seen in the cuticle, together with an increase in volume that distorts the striations of the cuticle and apparently results in the leaking out of internal matter $\left(\mathrm{T}_{1 \mathrm{~A}}\right)$. When compared to the body surface of the untreated control parasites $\left(\mathrm{C}_{1 \mathrm{~A}}\right.$ $\& \mathrm{C}_{2 \mathrm{~A}}$ ), there are transverse wrinkles of the cuticle all throughout the extension of the body $\left(\mathrm{T}_{2 \mathrm{~A}}\right)$. 
Figure 1. Electron-scanning microscope imaging showing the outer structure of Haemonchus contortus upon exposure to saline solution (C) and upon exposure to Acacia mearnsii extract (T).
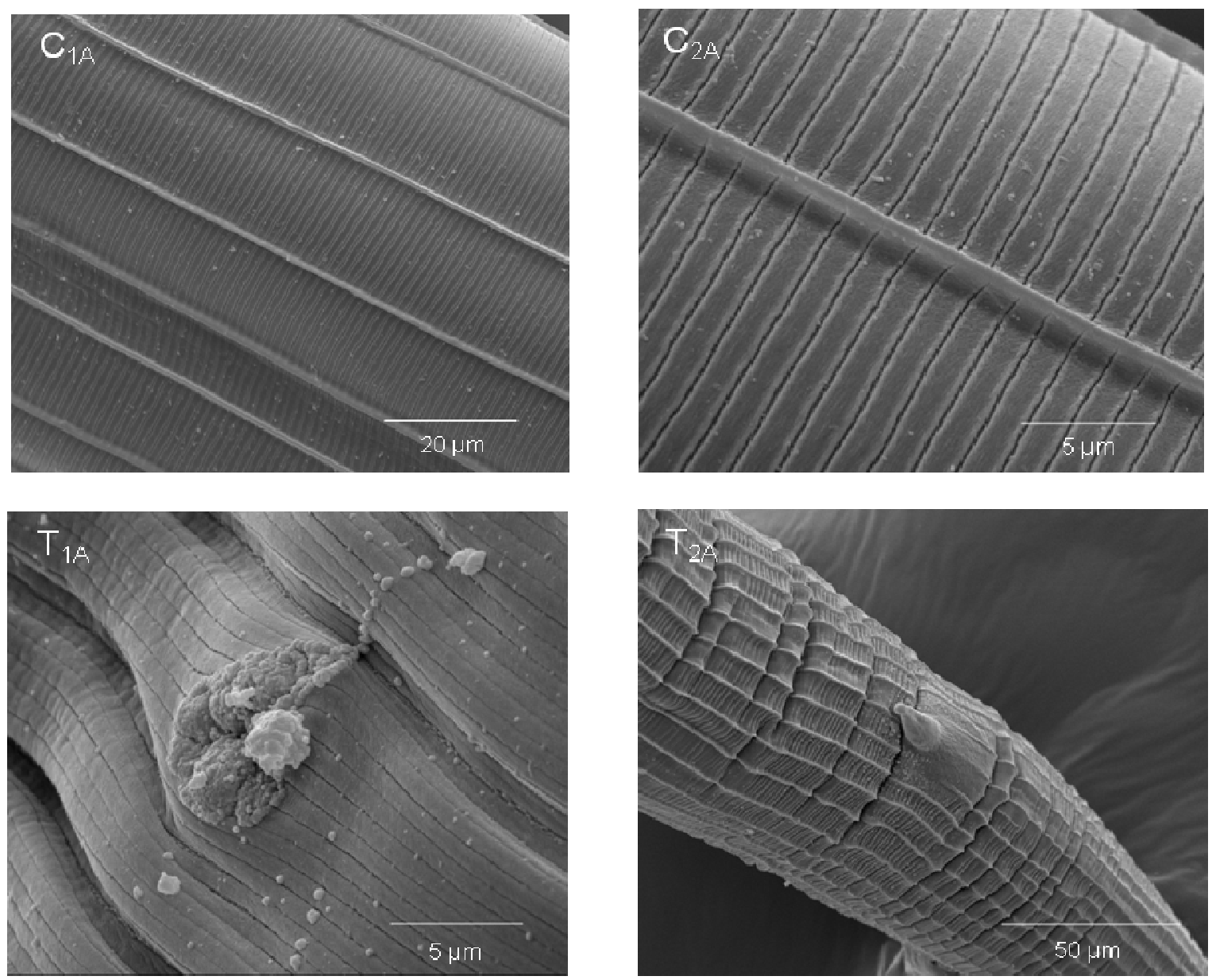

$\mathrm{C}_{1 \mathrm{~A}} \& \mathrm{C}_{2 \mathrm{~A}}:$ Normal cuticle (control).

$\mathrm{T}_{1 \mathrm{~A}}$ : Note the ruptured area on the cuticle with an increase of inner volume/pressure that has distorted the cuticular striations, causing obvious leakage of inner matter (AE treated).

$\mathrm{T}_{2 \mathrm{~A}}$ : Parasitic body surface showing transverse wrinkling (AE treated).

\section{Discussion}

The anthelminthic effects of different sources of CT were described for the last 15 years (HOSTE et al., 2006). These resulted have been were related to the effects in different phases of the parasite development as the elimination of nematode eggs (NIEZEN et al., 1998; BUTTER et al., 2000; MARLEY et al., 2003; MINHO et al., 2010), a reduction in the worm burden (TZAMALOUKAS, 2005; HECKENDORN et al., 2007; MARTÍNEZORTÍZ-DE-MONTELLANO et al., 2010; MAX, 2010), a decrease in the fertility of female parasites
(ATHANASIADOU et al., 2001; LANGE et al., 2006; HECKENDORN et al., 2007), and less information is available on the possible mode of action of tannins against adult worms. These results demonstrate the anthelminthic action of CT.

In this study, the anthelminthic effect of Acacia mearnsii extract was demonstrated by means result of ultrastructural modifications in the cuticles of $H$. contortus adults upon contact with the $\mathrm{AE}$ in in vitro conditions, as verified by ESM.

The anthelminthic efficacy using these same extracts were also evaluated in other studies (CENCI 
et al., 2007; MINHO et al., 2010; MAX, 2010), where the worm burden and FEC were decreased, and the feeding of first-stage larvae was inhibited, as well. The findings of these studies related before corroborate the results of our studies, confirming the effects obtained from utilizing Acacia mearnsii extract on $H$. contortus control.

The ultrastructural changes found in the $H$. contortus adult worm after the in vitro exposure are limited to the cuticle, where ruptures, an increase in volume that disrupts the cuticular striations and the leakage of internal matter can be observed. Transverse wrinkles can also be described.

Cuticular changes were described by Hoste et al. (2006), in which they also related modifications to Trichostrongylus colubriformis adult worm, along with the presence of longitudinal and transverse wrinkles after in vitro exposure to walnut extract rich in condensed tannin, as analyzed by ESM.

The presence of wrinkles in the cuticle was also described by Martínez-Ortíz-De-Montellano et al. (2013) upon observation by ESM of $H$. contortus adult worm when in in vitro contact with plants rich in tannins. These studies also demonstrate the effect of CT on the cuticle in in vitro experiments, confirming the results of our study.

The main purpose of the cuticles in nematodes is to maintain structural uniformity, thus allowing it to move and to selectively absorb nutrients, along with osmoregulation in the digestive system of its host (PAGE; WINTER, 2003). Based on the functions of the cuticle, the damage to the parasite structure described in this study could estimate an inhibit of the motility of the parasite, as well as cause an osmotic imbalance, thus compromising its interaction with its environment, primarily as it relates to the feeding and nutrition of the nematode.

The foundlings in assays are similar confirming the effect of AE on the nematodes cuticle. Therefore the use of in vitro test as an screening of CT sources with direct effect on $H$. contortus is recommended rather than in vivo test cause this kind of assay is less laborious and requires less number of experimental animals. Evaluate the direct anthelmintic effect of $\mathrm{CT}$ sources on $H$. contortus using electron-scanning microscope are promising, but further experiments and studies should be conducted to explore possible changes to the internal structures as a result of exposure to tannin-rich extracts.

\section{Conclusions}

Analysis by ESM reveals ultrastructural changes in $H$. contortus adult parasites after in vitro exposure to Acacia mearnsii extract when compared to the untreated control group. These changes are concentrated on the cuticle and in the cephalic region, thus demonstrating the direct action of CT on the subject parasites.

\section{Aprovação do Comite De Ética}

O presente trabalho foi executado obedecendo às normas técnicas de biosegurança e ética sob a aprovação do comite de ética em Experimentação Animal da Universidade Estadual de Londrina através do OF. CIRC. CEEA/UEL n 17/2010.

\section{References}

ATHANASIADOU, S. The effects of condensed tannins supplementation of foods with different protein content on parasitism, food intake and performance of sheep infected with Trichostrongylus colubriformis. British Journal Nutrition, Cambridge, v. 86, n. 6, p. 697-706, 2001.

BUTTER, N. L. Effect of dietary tannin and protein concentration on nematode infection (Trichostrongylus colubriformis) in lambs. Journal of Agricultural Science, Cambridge, v. 134, n. 1, p. 89-99, 2000.

CENCI, F. B.; LOUVANDINI, H.; MCMANUS, C. M.; DELL'PORTO, A.; COSTA, D. M.; ARAÚJO, S. C.; MINHO, A. P.; ABDALLA, A. L. Effects of condensed tannin from Acacia mearnsii on sheep infected naturally with gastrointestinal helminthes. Veterinary Parasitology, Amsterdam, v. 144, n. 1-2, p. 132-137, 2007. 
HECKENDORN, F.; HARING, D.A.; MAURER, V.; HERTZBERG, H. Individual administration of three tanniferous forage plants to lambs artificially infected with Haemonchus contortus and Cooperia curticei. Veterinary Parasitology, Amsterdam, v. 146, n. 1-2, p. 123-134, 2007.

HOSTE, H.; JACKSON, F.; ATHANASIADOU, S.; THAMSBORG, S. M.; HOSKIN, S. O. The effects of tannin-rich plants on parasitic nematodes in ruminants. Trends in Parasitology. Philadelphia, v. 22, n. 6, p. 253261, 2006.

HOSTE, H.; MARTINEZ-ORTIZ-DE-MONTELLANO, C.; MANOLARAKI, F.; BRUNET, S.; OJEDAROBERTOS, N.; FOURQUAUX, I.; TORRESACOSTA, J. F.; SANDOVAL-CASTRO, C. A. Direct and indirect effects of bioactive tannin-rich tropical and temperate legumes against nematode infections. Veterinary Parasitology, Amsterdam, v. 186, n. 1-2, p. 18-27, 2012.

KARNOVSKY, M. J. A formaldehyde-glutaraldehyde fixate of hight osmolality for use in electron microscopy. Journal Cell Biology, v. 27, n. 1, p. 137A-138A, 1965.

KATIKI, L. M.; FERREIRA, J. F.; GONZALEZ, J. M.; ZAJAC, A. M.; LINDSAY, D. S.; CHAGAS, A. C.; AMARANTE, A. F. Anthelmintic effect of plant extracts containing condensed and hydrolyzable tannins on Caenorhabditis elegans, and their antioxidant capacity. Veterinary Parasitology, Amsterdam, v. 192, n. 1-3, p. 218-227, 2013.

LANGE, K. C. Effect of sericea lespedeza (Lespedeza cuneata) fed as hay, on natural and experimental Haemonchus contortus infections in lamb. Veterinary Parasitology, Amsterdam, v. 141, n. 3-4, p. 273-178, 2006.

MARLEY, C. L.; COOK, R.; KEATINGE, R.; BARRET, J.; LAMPKIN, N. H. The effect of birdsfoot trefoil (Lotus corniculatus) and chicory (Cichorium intybus) on parasite intensities and performance of lambs naturally infected with helminth parasites. Veterinary Parasitology, Amsterdam, v. 112, n. 1-2, p. 147-155, 2003.

MARTÍNEZ-ORTÍZ-DE-MONTELLANO, $\quad$ C.; VARGAS-MAGAÑA， J. J.; CANUL-KU, H. L.; MIRANDA-SOBERANIS, R.; CAPETILLO-LEAL, C.; SANDOVAL-CASTRO, C. A.; HOSTE, H.; TORRES-ACOSTA, J. F. Effect of a tropical tanninrich plant Lysiloma latisiliquum on adult populations of Haemonchus contortus in sheep. Veterinary Parasitology, Amsterdam, v. 172, n. 3-4, 283-290, 2010.
M A RT ÍNEZ - ORTÍZ - D E - MON T E L L A N O, C.; ARROYO-LÓPEZ, C.; FOURQUAUX, I.; TORRESACOSTA, J. F. J.; SANDOVAL-CASTRO, C. A.; HOSTE, H. Scanning electron microscopy of Haemonchus contortus exposed to tanninn-rich plants under in vivo and in vitro conditions. Experimental Parasitology, New York, v. 133, n. 3, p. 281-286, 2013.

MAX, R. A. Effect of repeated wattle tannin drenches on worm burdens, faecal egg counts and egg hatchability during naturally acquired nematode infections in sheep and goats. Veterinary Parasitology, Amsterdam, v. 169, n. 1-2, p. 138-143, 2010.

MINHO, A. P.; BUENO, I. C. S.; LOUVANDINI, H.; JACKSON, F.; GENNARI, S. M.; ABDALLA, A. L. Effect of Acacia molissima tannin extract on the control of gastrointestinal parasites in sheep. Animal Feed Science Technology, Washington, v. 147, n. 1-3, p. 172$181,2008$.

MINHO, A. P.; FILIPPSEN, L. F.; AMARANTE, A. F. T.; ABDALLA, A. L. Efficacy of condensed tannin presents in acacia extract on the control of Trichostrongylus colubriformis in sheep. Ciência Rural, Santa Maria, v. 40, n. 6, p. 1360-1365, 2010.

NIEZEN, J. H.; ROBERTSON, H. A.; WAGHORN, G. C.; CHARLESTON, W. A. Production, faecal egg counts and worm burdens of ewe lambs which grazed six contrasting forages. Veterinary Parasitology, Amsterdam, v. 80, n. 1, p. 15-27, 1998.

PAGE, A. P.; WINTER, A. D. Enzymes involved in the biogenesis of the nematode cuticle. Advances in Parasitology, London, v. 53, n. 1, p. 85-148, 2003.

PORTER, L. J.; HRSTICH, L. N.; CHAN, B. G. The conversion of procyanidins and prodelphinidins to cyanidin and delphinidin. Phytochemistry, Kidlington, v. 25, n. 1, p. 223-230, 1986.

TZAMALOUKAS, O. The consequences of shortterm grazing of bioactive forages on established adult and incoming larvae populations of Teladorsagia circumcincta in lambs. International Journal for Parasitology, Oxford, v. 35, n. 3, p. 329-335, 2005.

WALLER, P. J. Sustainable nematode parasite control strategies for ruminant livestock by grazing management and biological control. Animal Feed Science Technology, Washington, v. 126, n. 3-4, p. 277-289, 2006. 